\title{
Perceptions of University of Calabar Professional Women on the Attainment of Peaceful Society through Gender Education in Cross River State, Nigeria
}

\author{
Odigwe Francisca Nonyelum ${ }^{1}$ \\ Sule Mary Anike ${ }^{1}$ \\ Alade Feyisayo $0 .{ }^{2}$ \\ ${ }^{1}$ Department of Educational Administration and Planning, Faculty of Education, University of Calabar, Calabar, Nigeria \\ ${ }^{2}$ Department of Catering and Food Sciences, Babcock University, llishan Demo, Ogun State, Nigeria
}

\author{
Doi:10.5901/jesr.2016.v6n1p129
}

\begin{abstract}
The present study investigated the perceptions of academic women in the University of Calabar on the possible strategies for the attainment of a peaceful society through educating the girl child in Cross River State, Nigeria. Subjects were a random sample of 180 out of 393 women academics in the University of Calabar, Nigeria, cutting across the 10 faculties in the university, with varied years of teaching experience. Their ages ranged from 35 to 58 years, with a mean of 46.2 and a standard deviation of 3.6. A questionnaire was designed by the researchers to collect data for this study. A reliability index of ' $r$ ' 0.68 was obtained for questionnaire consistency using a test-retest method. In each faculty visited for data collection, all female Lecturers available and willing to participate in the study responded to the questionnaire and returned them on the spot. Frequencies and percentages were used to summarise the data. The findings indicate that: provision of scholarship to females; educating parents/community leaders on the value of women education in nation building; formulating and enforcing policies that will de-emphasise early marriage and commercial sex and the use of women role models to motivate the girl-child were very popular approaches considered by subjects. The implications for peace and security in society are discussed.
\end{abstract}

Keywords: education, access, female, women, development

\section{Introduction}

One of the major challenges that Nigeria faces today is insecurity arising from different forms of conflicts, such as; religious crisis, kidnappings, insurgency, ethnic militancy and other violent crimes. These security challenges pose problems to the very core of all spheres of society (politics, economy health and education). For instance, violent conflicts, which often manifest through land disputes and tribal wars account for a high proportion of human, social and economic loses. Therefore, there is need for peace and developmental initiatives to address this monster and in the process promote harmony and development. Education has been identified as a major means of empowerment through which all men and women realize their potentials (World Bank, 1996 and UNESCO, 2007). It is one of the instruments through which individuals are equipped to participate in the socio-economic and political life of their communities and to contribute positively to social change including peace, particularly, women education (Ekuri \& Isangedigi, 2003).

\section{Literature Review}

A critical limitation to women empowerment is illiteracy. According to the United Nations Department of Economics and Social Affairs (UNDESA) (2007) females constitute about 49 percent of Nigeria's total population, yet, 61 percent of the total female population are illiterate, indicating that females are grossly under-represented in education. This is in spite of the high social and economic return on investment in female education in developing nations. In addition to the foregoing, and according to (UNDESA, 2007), women still account for over $60 \%$ of unpaid family workers with more girls than boys remaining out of school.

As long as women remain illiterate and are subject to discrimination in education, the motivation for change to improve the quality of life for all will fail. In most African societies, it is the mother that is responsible for the training of the children during their formative years. How? The mother spends more time with the children at home. She teaches them how to communicate in both the local and English language if she is educated. She teaches them how to keep the home 
environment clean, how to cook, how to relate with people and also how to count, read and write. For women as a social group, education gives them a better opportunity to control their lives, to earn money, to be better mothers and to have improved relationships with their spouses.

Masanja (2010) comments that "The culture of marginalisation and discrimination of the women folk in education has persisted to this day" (p.2) The author further observes that education is typically "gendered" because during formal education knowledge as well as skills are stereotyped, thus, exacerbating the marginalisation and exclusion of women from educational opportunities.

Women education brings a lots of collateral benefits such as; reduced infant mortality, regulated fertility rates, greater and higher economic production, improved family and child nutrition, better resource utilization, higher life expectancy for men and women etc (Lockleed \& Verspoor, 1994; World Bank, 1996). The UN Women Watch (2011) submitted thus:

The Commission recognizes the potential of education and training and science and technology, to contribute to the economic empowerment of women, which also leads to accelerating progress towards achieving the internationally agreed development goals, including the Millennium Development Goals, by 2015.(p1)

Lopez-Claros and Zahidi, (2010) have also pointed out that the education of women has a very wide-reaching implications for national wellbeing.

Promoting and increasing girls' access to basic education therefore would afford women greater opportunity to take meaningful part in the economic development of societies. The foregoing underscores the need for increasing female participation in formal schooling, because when more women are educated the social and economic return on their training is also increased, with ultimate reduction in security challenges and a concomitant increase in societal peace.

\section{Objective}

This paper sought the perspectives of professional women in a Nigeria tertiary institution on how female could have increased access to education

\section{Research Question}

A pertinent question therefore is: What are the views of women academics on the approaches/strategies for increasing female participation and progress in schools?

\section{Methodology}

\subsection{Design and sample}

This study adopted the survey research design because it depended on the opinions and perspective of the respondents to draw inference about the phenomenon under study. It is used since the study assessed "thoughts, opinions, and feelings" (Shaughnessy, J.; Zechmeister, \& Jeanne, 2011). The participants were 180 academics out of a total 393 women in the university with various years of teaching and ages $(35-58)$ years.

\subsection{Instrument and data collection}

A questionnaire was designed by the researchers to collect the requisite data. The questionnaire has two parts. (see appendix I) Section A elicited biodata information on the following demographic variables: age, sex, educational qualification, subject taught and years of teaching experience. Section B elicited information on the approaches/strategies that could increase female participation and progression in school. A reliability index of ' $r$ ' $=0.68$ was obtained for the questionnaire using test-retest method. Respondents were female lecturers in each faculty. From Faculty of Agriculture, Forestry \& Wildlife Resource Management, 18; Faculty of Allied Medical Sciences, 60; Faculty of Art, 54; Faculty of Basic Medical Sciences, 24; Faculty of Education, 101; Faculty of Law, 4; Faculty of Management Sciences, 15; Faculty of Medicine and Dentistry, 27; Faculty of Science, 47; Faculty of Social Sciences, 24; responded to the questionnaire and returned it on the spot. 


\subsection{Method of data analysis}

Frequency and percentages were used to present and describe the result. The frequency for each type of response was determined and further converted to percentage to show the relative proportion of women that chose a particular approach/strategy. Based on this, a frequency distribution table was prepared for the data.

\section{Results}

Table I: Women academics Perspective of approaches/strategies for increasing Female Participation and progression in School

\begin{tabular}{clcc}
\hline S/N & Approach/Strategy Description & Frequency & Percentage \\
\hline $\mathbf{1}$ & Provision of scholarship to females & 172 & 95.6 \\
2 & Educating parents/community leaders on the value of women education in nation building. & 167 & 92.8 \\
3 & Formulating and enforcing policies that will de-emphasise early marriage and commercial sex. & 162 & 90 \\
4 & The use of women role models to motivate the girl-child & 160 & 88.9 \\
$\mathbf{5}$ & Development of sound women mentorship programmes & 128 & 71.1 \\
$\mathbf{6}$ & Promotion of female clubs in schools & 120 & 66 \\
7 & Prohibition of girl-child trafficking & 87 & 48.3 \\
$\mathbf{8}$ & Reduction of fees for female education. & 84 & 46.7 \\
\hline
\end{tabular}

Table 1 shows professional women's views regarding methods/approaches for increasing female participation in school. The Actual numbers (frequency) and percentages for responses to each method/approach are shown in the table. The table shows that generally, the women used in this study, perceived 8 approaches/strategies as useful in increasing female participation in school. Specifically, a greater proportion of the subjects (above 50\%), considered only 6 out of the 8 approaches/strategies as effective for increasing female participation in school. Top on this list is, provision of scholarship to females (95.6\%). The others in order of decreasing frequency are: educating parents/community leaders on the value of women education in nation building (92.8\%); formulating and enforcing policies that will de-emphasise early marriage and commercial sex (90\%); the use of women role-models to motivate the girl-child (88.9\%); development of a sound women mentorship programmes (71.1\%); and promotion of female clubs in schools (66\%). The table also shows that less than half of the women have two other approaches/strategies for increasing female participation in school. These are: Prohibition of girl-child trafficking (48.3\%); Reduction of fees for female education (46.7\%).

\section{Discussion of Findings}

Most of the women academics who participated in this study seem to be more favourably disposed to the following strategies/approaches as effective in increasing enrolment of female students in school: provision of scholarship to females; educating parents/community leaders on the value of women education in nation building; formulating and enforcing policies that will de-emphasise early marriage and commercial sex; the use of women role models to motivate the girl-child; development of sound women mentorship programmes; and promotion of female clubs in schools.

Providing scholarship to females will reduce the economic burden of parents on education. This is important in the sense that, the high cost of education has often compelled low-income parents to make choices as to which children should be educated. Emunemu (1998) maintained that when such choices have to be made, the girl-child is always at a disadvantage. Reducing the cost of female education would certainly augur well for the female fold and the ultimately the entire society. This could be achieved through tuition waivers, scholarships and provision of school uniforms, where and when practicable. In fact, emerging literature on increasing female access to education revealed that, tuition waivers has a strong signalling effect for parents on the importance given to the education of girls (Hyde, 1994).

Educating parents/community leaders on the value of women education in nation building is also important, because if they were fully aware of the importance of education for females, they would willingly support and encourage their increased participation in schooling. The task of educating parents and community leaders could be easily achieved through public education campaigns, utilizing both the print and electronic media as well as through seminars and workshops. In this way, parents would be aware of the benefits of not only educating their daughters, but also giving them qualitative education.

Formulating and enforcing policies that will de-emphasise early marriages in our society is particularly important 
for girls in Northern Nigeria, who because of cultural practices, girls as young as 14 years of age may be married to a man 4 or 5 times her age! In communities such as these, female participation will be very low. In fact the situation has become more horrible with the passage of the bill for early marriage in Nigeria by the Senate of the Federal Republic of Nigeria!

The importance of women role-models and female clubs in schools for women education and development has long been recognised and emphasized (Miguel, Kreme \& Thorton, 2010). For instance, studies including that by Friedman (2012) have shown that orientation which can be achieved through role-models is a valuable technique for channelling peoples' time and energy into useful ventures. This implies that the role-models have to function effectively to ensure that there is a re-orientation of the attitude of female students' attitude towards education and schooling. This will help revalue themselves upwards, reorder their lives positively and participate fully in school activities with maximum focus and concentration.

\section{Conclusion}

The result of this study illustrated the following significant characteristics of women academics' perspective on effective strategies/approaches for increasing participation of females in schools as very popular: provision of scholarship to females; educating parents/community leaders on the value of women education in both home and nation building; formulating and enforcing policies that will de-emphasise early marriage and commercial sex; and the use of women rolemodels to motivate the girl-child. This study has implication for more research. Further research should focus on the impact of each of the strategies/approaches identified in this study on female participation and progression in school.

\section{References}

Ekuri,E.E. \&lsangedigi(2003). The Effect of Cooperative Learning Strategy in fostering Gender equity in Science concept attainment in a Nigerian Setting. Education for Today, 3(3), 77-84.

Emunemu, B.O. (1999). The Gender gap in Basic Education: Evolving strategies to

increase girls' access. In J.O. Obemeata; S. O. Ayodele; \& M. A. Araromi (Eds.) Evaluation in Africa. Institute of Education, University of Ibadan, Ibadan; 360-367.

Friedman, T. (2012). "Why the world is flat" Wired. May 2005. Retrieved February 6, 2012.

Hyde,K.(1994).Gender streaming as a strategy for improving girls Academic performances: Evidence for Malawi. A Publication for the Centre for Social Research, University of Malawi.

Lockheed, M. E. and Verspoor, A.M. (1994). Improving Primary Education in developing countries. New York: Oxford University Press.

Lopez-Claros, A. and Zahidi, S., (2007). Women's Empowerment: Measuring the Global Gender Gap. World Economic Forum.

Masanja, V.G.(2010). Increasing Women's Participation in Science, Mathematics and Technology Education and Employment in Africa. Expert group meeting Gender, science and technology. Retrieved from: http://www.un.org/womenwatch/daw/egm/gst_2010 IMasanja-EP.8-EGM-ST.pdf

Miguel, E., Kremer M. and Thornton R. (2010). Incentives to learn, Review of economics and statistics, 91(3): 437-56.

National Planning commission (1992). National Programme of Action for the survival, protection and development of the Nigerian Child. Lagos: Federal Government of Nigeria.

Shaughnessy, J.; Zechmeister, E.; Jeanne, Z. (2011). Research methods in psychology (9th ed.). New York, NY: McGraw Hill. pp. 161175

UNESCO Abuja (2000). The state of Education in Nigeria. Abuja: UNESCO.

United Nations Department of Economic and Social Affairs (2007). The Millennium Development Goals Report, 2007, New York.

United Nations Statistics Division, UNSD (2007). http://www.naptip.gov.ng/naptip/docs/UNSD_MDG_Report_2007e00008.html

United Nations Women Watch (2011). Agreed conclusions on access and participation of women and girls in education, training and science and technology, including for the promotion of women's equal access to full employment and decent work. Retrieved from: www.un.org/womenwatch/daw/csw/csw55/agreed_conclusions/AC_CSW55_E.pdf

World Bank (1996). World Development Report, 1996. New York; Oxford University Press. 